\title{
Vitenskapelige nigeriabrev
}

\author{
Terskelen for å bli invitert til å bli medlem i en redaksjonskomité kan noen ganger være lav.
}

Jeg skrev en artikkel i Språkspalten i Tidsskriftet nr. 6/2013 (1) om ordet «fortetning», som brukes om både lungeforandringer og overbelegg på sengeposter. Artikkelen ble indeksert i PubMed med den engelske tittelen Densification. Noen måneder senere fikk jeg en hyggelig e-post fra Lily Moris, redaksjonsassistent i Sciedu Press i USA. E-posten begynner slik: «Dear Dr. Kashif Waqar Faiz, I have had an opportunity to read your article «Densification» on Tidsskr. Nor. Laegeforen.. Through your works, I know you are a specialist in this area. I am the editor of International Journal of Diagnostic Imaging, a publication of Sciedu Press. It is my honor to invite you to join in the International Editorial Reviewer Board of International Journal of Diagnostic Imaging (IJDI). I think you are the perfectly suitable person for this position.»

Jeg er generelt takknemlig for positive tilbakemeldinger, men er svært usikker på om redaktøren eller redaksjonsassistenten virkelig har lest artikkelen i Språkspalten (som for øvrig kun finnes på norsk). I tillegg synes jeg at det kanskje er i overkant å bli titulert som ekspert innen bildediagnostikk på bakgrunn av en artikkel som omhandlet språk og terminologi mer enn fortetninger. Riktignok er jeg nevrolog og har gjort mange ultralydundersøkelser av halskar på slagpost, men jeg synes ikke det rettferdiggjør å sitte i redaksjonskomiteen til et internasjonalt bildediagnostisk tidsskrift.

\section{Røvertidsskrifter}

International Journal of Diagnostic Imaging er, ifølge hjemmesiden, et fagfelle- vurdert open access-tidsskrift som er en faglig plattform for klinikere og forskere til å bidra med innovativt arbeid innen bildediagnostikk (2). IJDI inneholder originalartikler som gjenspeiler den nyeste forsk-

\section{«Det kan være fristende à pynte på CV-en med flotte titler»}

ningen og utviklingen innen både teoretiske og praktiske aspekter ved bildediagnostikk. Publiseringskostnadene per artikkel er beskjedne 200 amerikanske dollar.

Erlend Hem skrev i Tidsskriftet nr. 12-13/ 2014 (3) om røvertidsskrifter som useriøse aktører innen akademisk publisering, der målsettingene ikke er vitenskapelige, men kommersielle. Temaet er også belyst av Tidsskriftets redaktør i en artikkel i New England Journal of Medicine (4).

Selv med en beskjeden publikasjonsliste mottar jeg ukentlig useriøse, masseproduserte e-poster med invitasjoner til å sende inn manuskripter, delta på kongresser (gjerne som «main speaker») eller sitte i redaksjonskomiteer. Tidsskriftenes navn er ofte mistenkelig like navnene på anerkjente tidsskrifter.

Det kan være fristende å pynte på CV-en med flotte titler eller rask og effektiv publisering av egne forskningsresultater, men verdien av slike titler og publiserte artikler er tvilsom. Dette er langt fra et unikt tilfelle.
Eksemplet viser mangelen på kvalitetssikring og hvor liten vitenskapelig bakgrunn slike tidsskrifter krever. Vi bør passe oss for slike vitenskapelige nigeriabrev.

\section{Kashif Waqar Faiz}

kashif.faiz@medisin.uio.no

Kashif Waqar Faiz (f. 1978) er spesialist i nevrologi og konstituert avdelingssjef ved Avdeling for akuttmedisin, Medisinsk divisjon, Akershus universitetssykehus.

Forfatter har fylt ut ICMJE-skjemaet og oppgir ingen interessekonflikter.

Litteratur

1. Faiz KW. Fortetning. Tidsskr Nor Legeforen 2013; 133: 668.

2. International Journal of Diagnostic Imaging www.sciedu.ca/journal/index.php/ijdi (17.7.2014).

3. Hem E. Se opp for røvertidsskrifter. Tidsskr Nor Legeforen 2014; 134: 1273.

4. Haug C. The downside of open-access publishing. N Engl J Med 2013; 368: 791-3.

Mottatt 17.7. 2014 og godkjent 5.8. 2014. Redaktør: Hanne Støre Valeur.

Publisert først på nett. 